Mansilla E Gómez-Ortiz, 2018

Volume 4 Issue 3, pp.309-322

Date of Publication: 22nd November 2018

DOI-https://dx.doi.org/10.20319/pijss.2018.43.309322

This paper can be cited as: Ubeda Mansilla, P. E Gómez-Ortiz, M. (2018). A Cross-Metaphorical

Mapping Video Poster for ESL Students. PEOPLE: International Journal of Social Sciences, 4(3), 309322.

This work is licensed under the Creative Commons Attribution-NonCommercial 4.0 International License. To view a copy of this license, visit http://creativecommons.org/licenses/by-nc/4.0/ or send a letter to Creative Commons, PO Box 1866, Mountain View, CA 94042, USA.

\title{
A CROSS-METAPHORICAL MAPPING VIDEO POSTER FOR ESL STUDENTS
}

\author{
Paloma Úbeda Mansilla \\ School of Architecture \& Sports Science, FacultyUniversidad Politécnica de Madrid, Spain \\ paloma.ubeda@upm.es \\ María-José Gómez-Ortiz \\ School of Architecture \& Sports Science, FacultyUniversidad Politécnica de Madrid, Spain \\ maria.gomez.ortiz@upm.es
}

\begin{abstract}
This paper describes a teaching and learning video poster tool designed for students of Architecture and students of Sports Science (ESL) as a second language at the Technical University of Madrid. These two major groups of students share a cross-metaphorical mapping that can be used as a cognitive approach to learn vocabulary in context using images and contexts closed to their field of studies. The metaphorical cross-mapping activity was the result obtained after publishing a bilingual dictionary handled under the research group of DISCYT from the Technical University of Madrid. The results obtained from them show a very fruitful and innovative material creation for (ESP) teaching in specific contexts. Additionally, the video poster provided additional written and oral task activities to work out in class.
\end{abstract}

\section{Keywords}

Architecture, Sports Science, Video Poster, Metaphorical Mappings, Languages Teaching 


\section{Introduction}

The DISCYT research group was immersed in an extensive study that was the complexion of creating a Bilingual Dictionary of Scientific and Technical Metaphors and Metonymies Cuadrado-Esclapez, et alt. (2016). This practical dictionary fills a gap in the field of technical language and provides students within the fields of science, engineering or sports science with a tool to understand a more complex language. During this project research we had the opportunity of observing how cognitive maps arise as common, came across from one field to another or emerge with identity in their fields themselves. Thus, we thought we could design interdisciplinary tasks with our students in order to make them aware of the richness of these maps vocabulary and at the same time improve and motivate their learning on specific vocabulary. This approach was based on previous studies (Cameron and Low 1999) where metaphor theory, the nature of metaphorical language, metaphor as process and product, teachers and learners use of metaphor are involved.

As members of the DISCYT project and having worked on these field disciplines so different between it was interesting to find the opposite maps +THE BUILDING IS A BODY+ and +THE BODY IS A CONTRUCTION+. Such metaphors structure are most basic understandings of their experience, they are "metaphors we live by"—metaphors that can shape students perceptions and actions without our ever noticing them as George Lakoff and Mark Johnson (1980) recalled. In the contextualization process, students had to connect disciplines and embed common ideas to compile a common fabric. Students were asked to build the concepts across disciplines and were coached in the process of thinking and building the conceptual maps. Bloomer, K. \& C. Moore. (1977). Previous research on education was taking by Gromik, N.A (2011) using video task recorded with mobile phone tools to motivate and achieve students' knowledge. Also, Shanahan, L. Ortlieb, E. McVee, M. (2015) research publication collets a series of practical activities and experiences using video in class from a wide scope. Balte and Balciuniene (2018) authors invite to use educational methods aimed at developing creativity in youth.

This work aims to create and carry on interdisciplinary proposals to improve vocabulary using a cognitive approach in our daily teaching routine. We have pioneered a new approach for more effective teaching and learning through cross-disciplinary technical metaphors. To design a video poster gathering the most important concept to be used in our English class was a 
challenge due to that the Video Poster was going to be used with two different students' profile. Thus, the structure and design of the message must be clear and understandable for all of them. Also a friendly use to teachers and students, as well as length timing was considered. The final result was a dynamic and understandable message to make our students aware of a very common and well used cross-metaphorical mapping.

\section{Video Poster Methodology}

The idea is to work with conceptual maps and use the metaphorical language involved as an example of teaching ESL in a Higher education context such as ARCHITECTURE and SPORT. So we decided to:

Firstly, activate metaphorical common sources and knowledge of the world students live in to stimulate them and develop awareness about the meaning of metaphors and enhance their autonomy. Secondly, focus on the target metaphors belonging to these Conceptual Metaphors (CMs) present in the two fields (sports and architecture). Thus, enhance awareness of the relationships that connect the literal and figurative meanings to build conceptual mappings and enhance learning and professional communication.

If we think about THE BODY IS A BUILDING, body is the source domain whose terminology is applied to the target domain of architecture to express control of the body and building of a strong human structure. In the case THE BUILDING IS A HUMAN BEING, building is the source domain whose terminology is applied to the target domain of human being in order to express emotion, beauty and pathologies that affect humans in an attempt to humanize the buildings.

In order to group them under CMs and see the connections and mappings, we suggested classifying the expressions under these groupings: anatomy, postures and training \& games Not only this, students worked the association between expressions and images to practice dual coding and thus enhance retention and metaphorical awareness as Gomez-Ortiz M.J. (2018) gathered.

Focused on THE BODY IS A BUILDING and THE BUILDING IS A HUMAN BODY, we thought about presenting a visual image with a simple and clear message in each visual shoot. All together were ten images with ten short audio messages. Image and message are summarized as follow: 
- ANATOMY: building, axis, piled, support beam, hollow, structure, floor

In the Anatomy classification students worked every aspect of the human body-not just structural anatomy, but also conception and growth.

- POSTURES: metal bars, barrage, arch, bridge, block, corner, board, Wall, crane In the Postures grouping students worked body control, position and movement.

- TRAINING and GAMES: gantry, charge, block, thrown \& break down, break through, defensive wall, pyramid, etc.

In the Training classification students worked with actions, then draw labour, with pulling, pushing, carrying, stopping, supporting and similar things.

- (Eye) SPORTS: positions on the field, physical training, parts of the body, sport objects, gymnastic positions.

Sport words: As can be seen from the examples and classification, BODY a highly productive source domain that aids vocabulary learning. With the help of the target domain "building" fertile and successful correspondences are created.

- Cartoons in sport:

Once students have the connection between source domain and target domain, they worked their willingness to communicate through the use of cartoons and real possible situations that worked learner autonomy, professional metaphor awareness and enhanced communication.

Cartoons sport examples in context: the concept of building gives the idea of body control an athlete should have in order to build a better body or a better training.

- (Eye) ARCHITECTURE: elements that stop you from passing, those allow you to pass, transition elements, materials, constructive elements, constructive techniques.

Architecture words: The patterned way that group words together provide a fruitful bunch of "body" correspondences"

- Cartoon architecture example in context: The body has underpinned architectural thinking with regards to the functional structure as well as ornamentation of building. The building is a body, is the clearest explanatory metaphor used by architects when talking about their projects at work.

Concept summary: On the one hand, architects want to transmit feelings or a sense of human being. On the other hand, an athlete needs to feel the sense of grandeur, strength and 
stability of the building. Students work creative thinking that is grounded in reality and engaged with the real world.

The next section presents the video poster shoot and the summary message that summaries the idea we wanted to provide.

\section{Video Poster images and messages}

\subsection{Video shoot}



Figure 1: The metaphors

Message 1: The metaphors THE BODY IS A BUILDING and THE BUILDING IS A HUMAN BEING are the two major metaphors the students live by in their daily communication routine. 


\subsection{Video shoot}

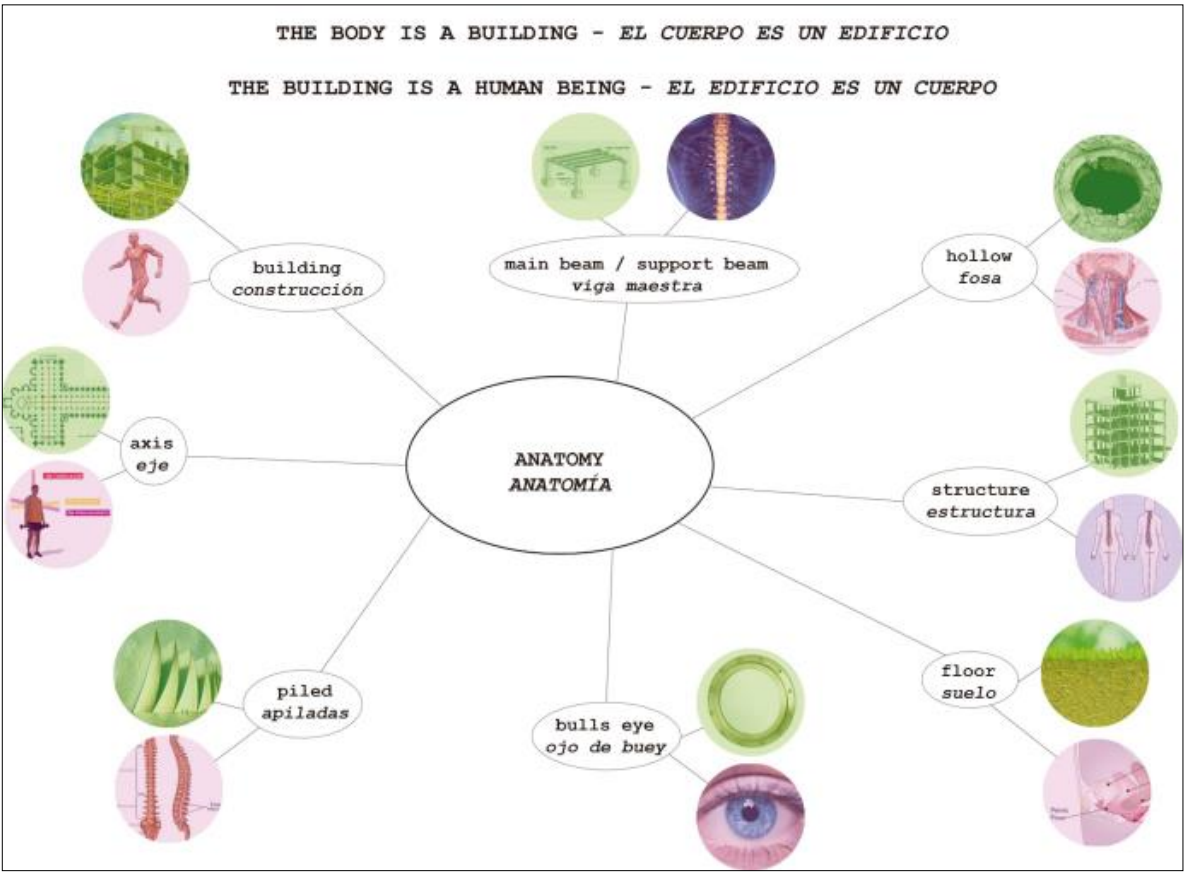

Figure 2: The body is a building

Message 2: In the Anatomy classification, students work every aspect of the human body-not just structural anatomy, but also conception and growth.

\subsection{Video shoot}

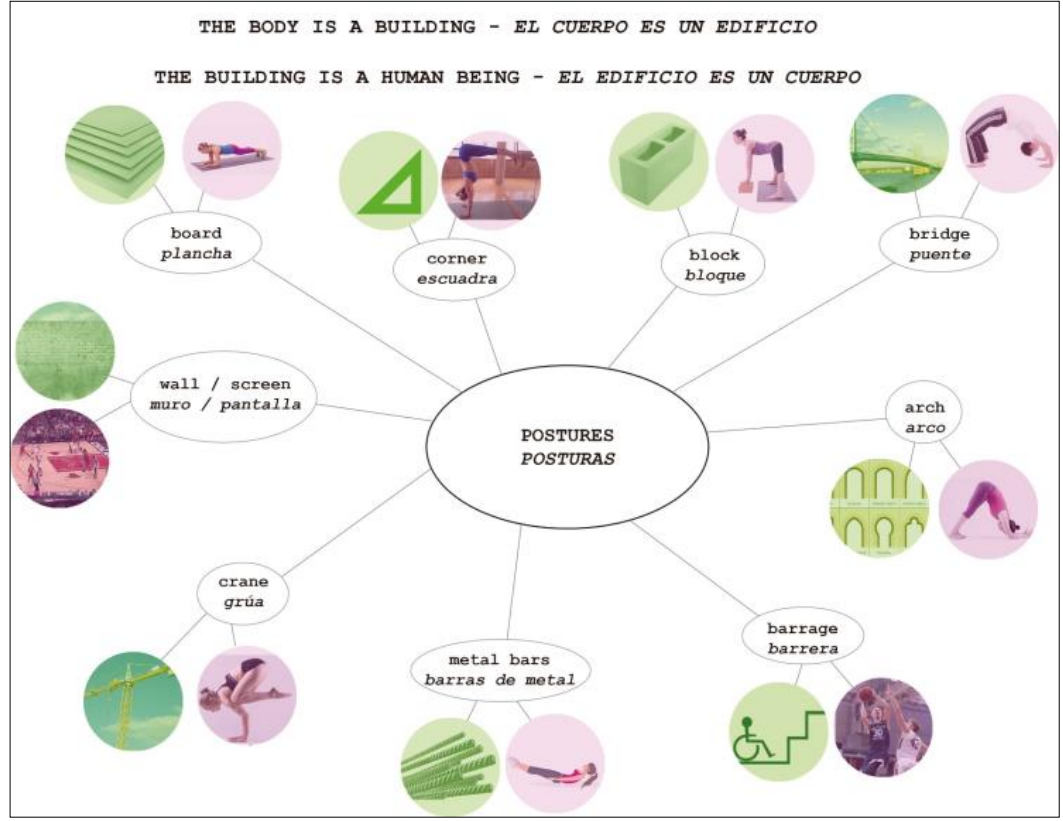

Figure 3: Postures 
Message 3: In the Postures students work body control, position and movement.

\subsection{Video shoot}

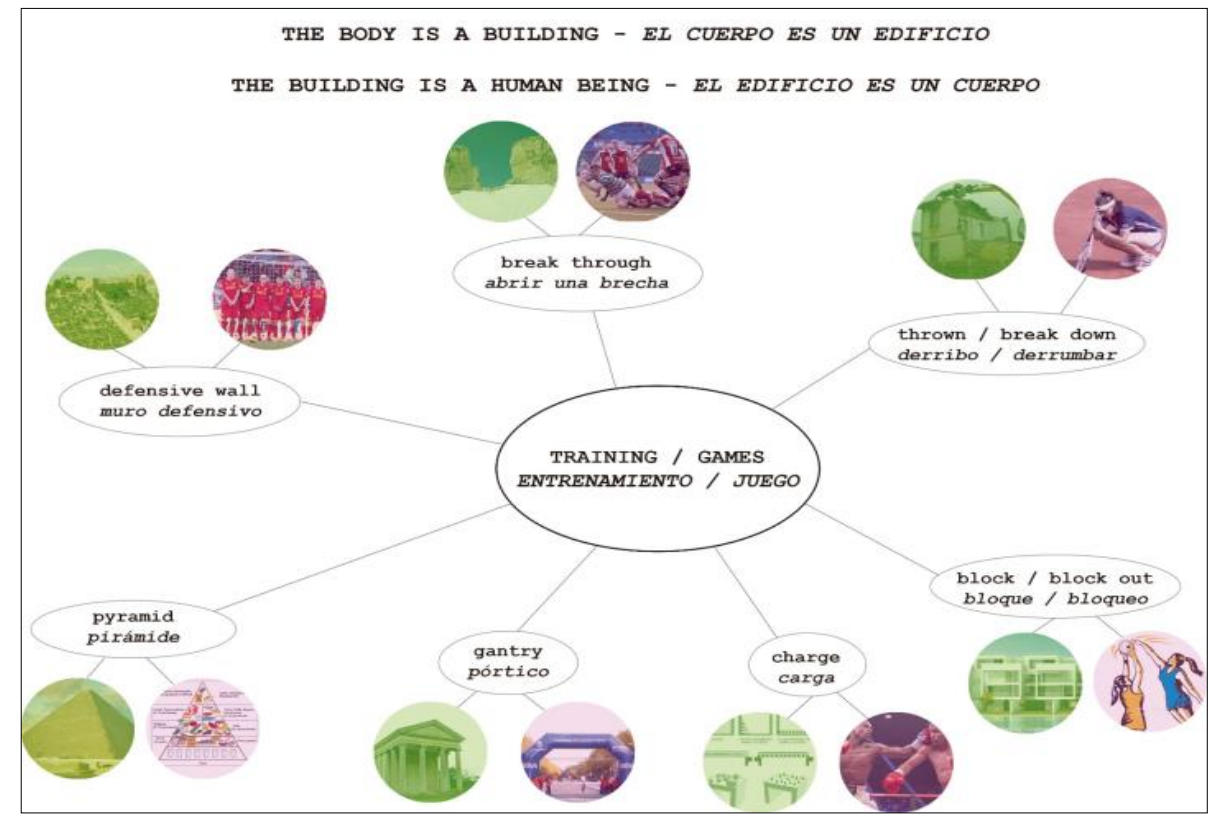

Figure 4: Training

Message 4: In the Training classification students work with actions, then draw labour, with pulling, pushing, carrying, stopping, supporting and similar things. 


\subsection{Video shoot}

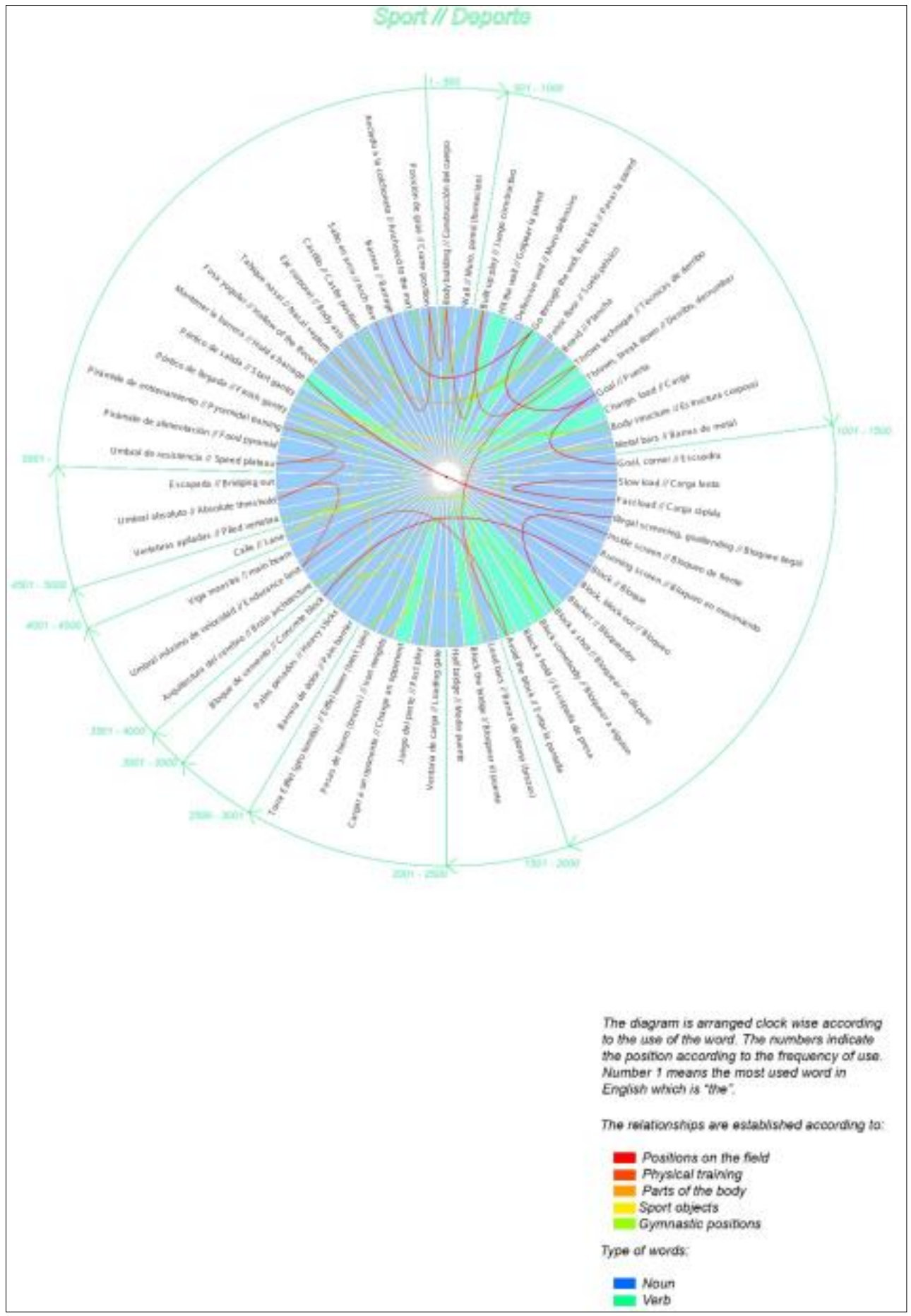

Figure 5: Sport words

Message 5: In Sport words: As can be seen from the examples and classification, BODY is a highly productive source domain that aids vocabulary learning. 


\subsection{Video shoot}

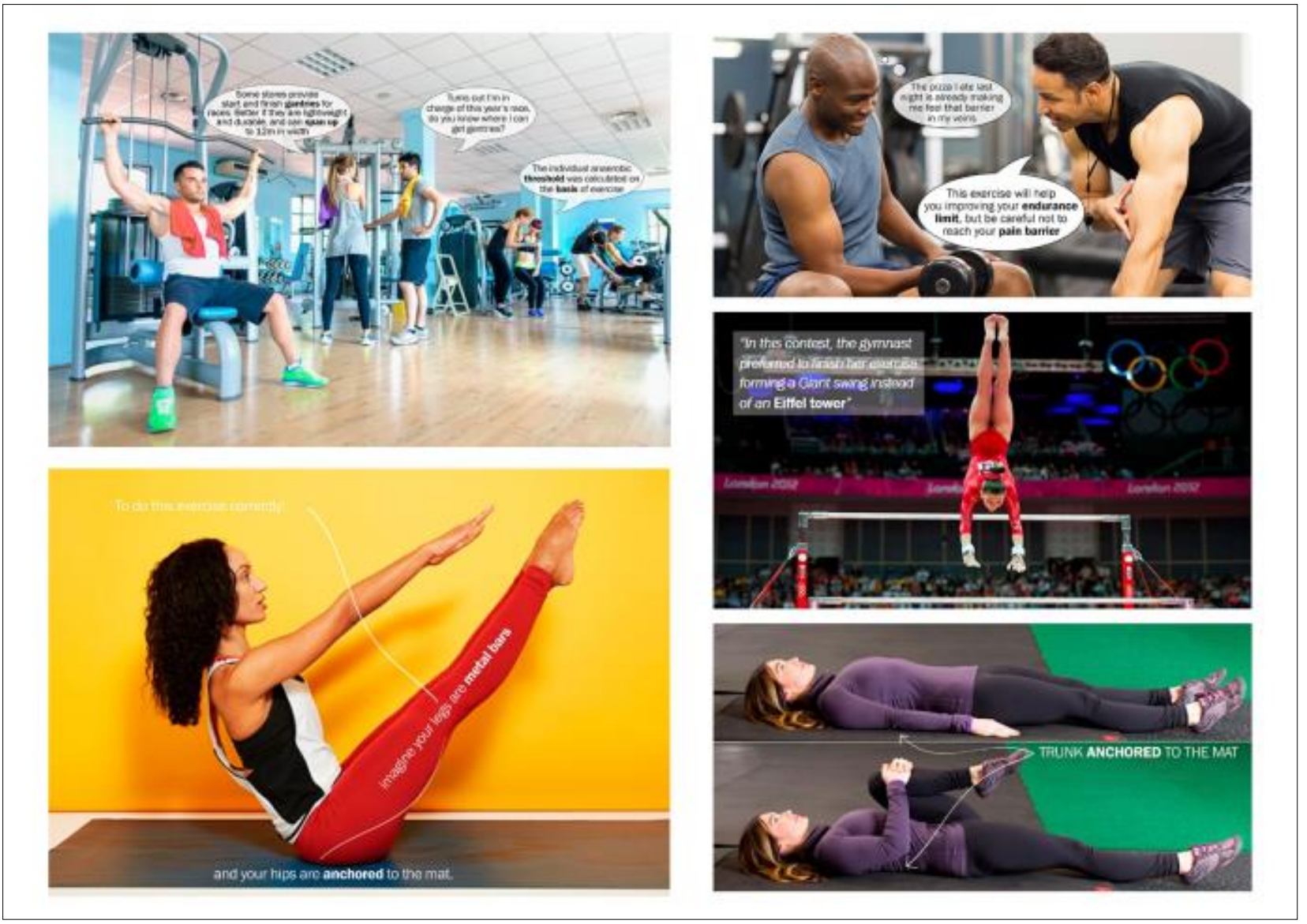

Figure 6: Sports examples in real contexts

Message 6: The concept of building gives the idea of body control an athlete should have in order to build a better body or a better training. 


\subsection{Video shoot}

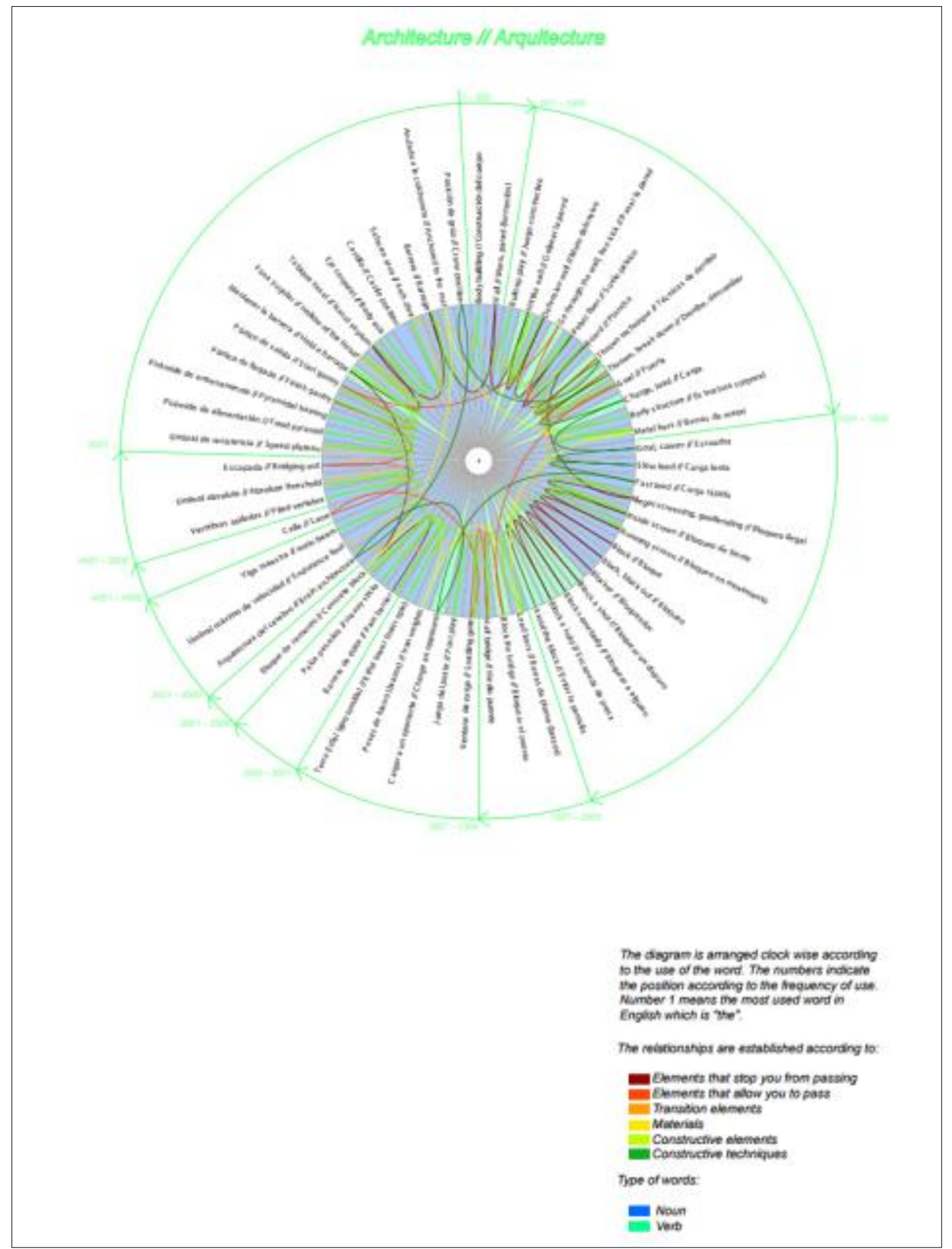

Figure 7: Architecture words

Message 7: Architecture words: The patterned way that group words together provide a number of "body" correspondences 


\subsection{Video shoot}

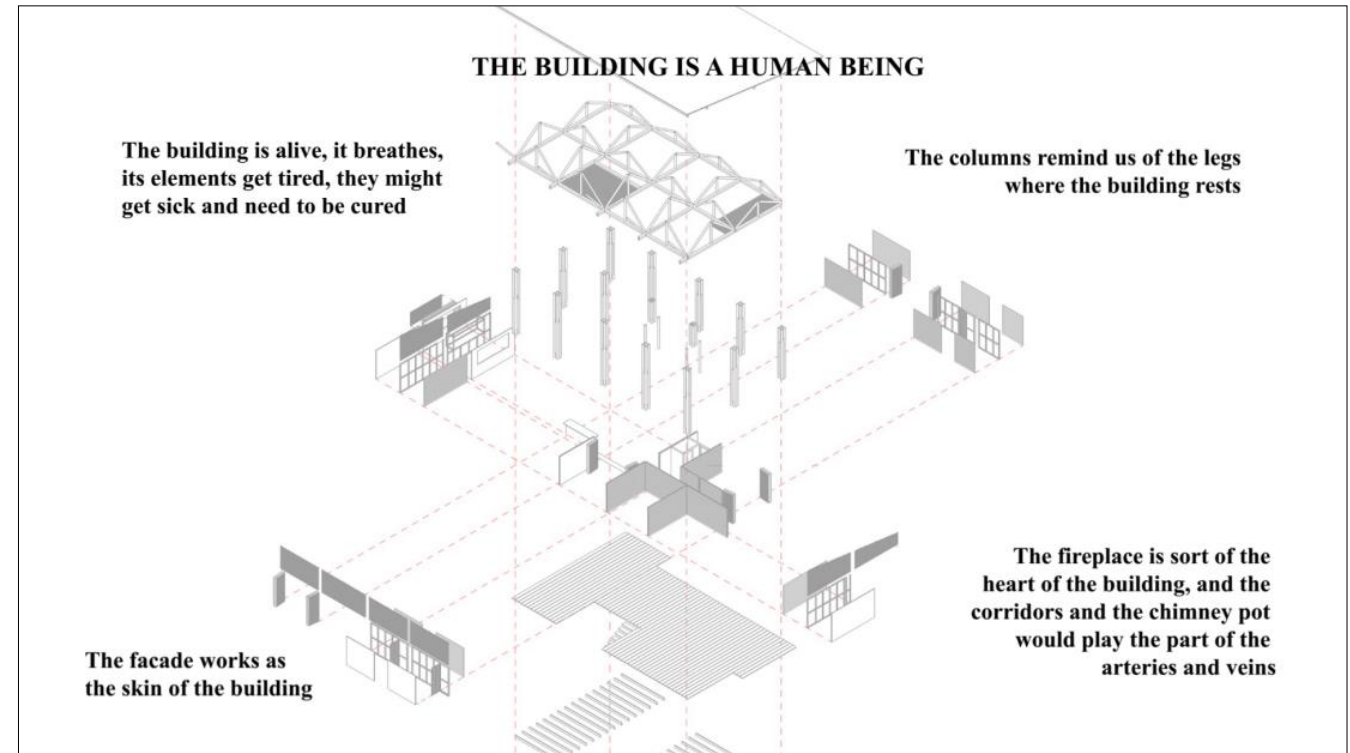

Figure 8: Architecture examples in real contexts

Message 8: The body has underpinned architectural thinking with regards to the functional structure as well as ornamentation of the building.

\subsection{Video shoot}

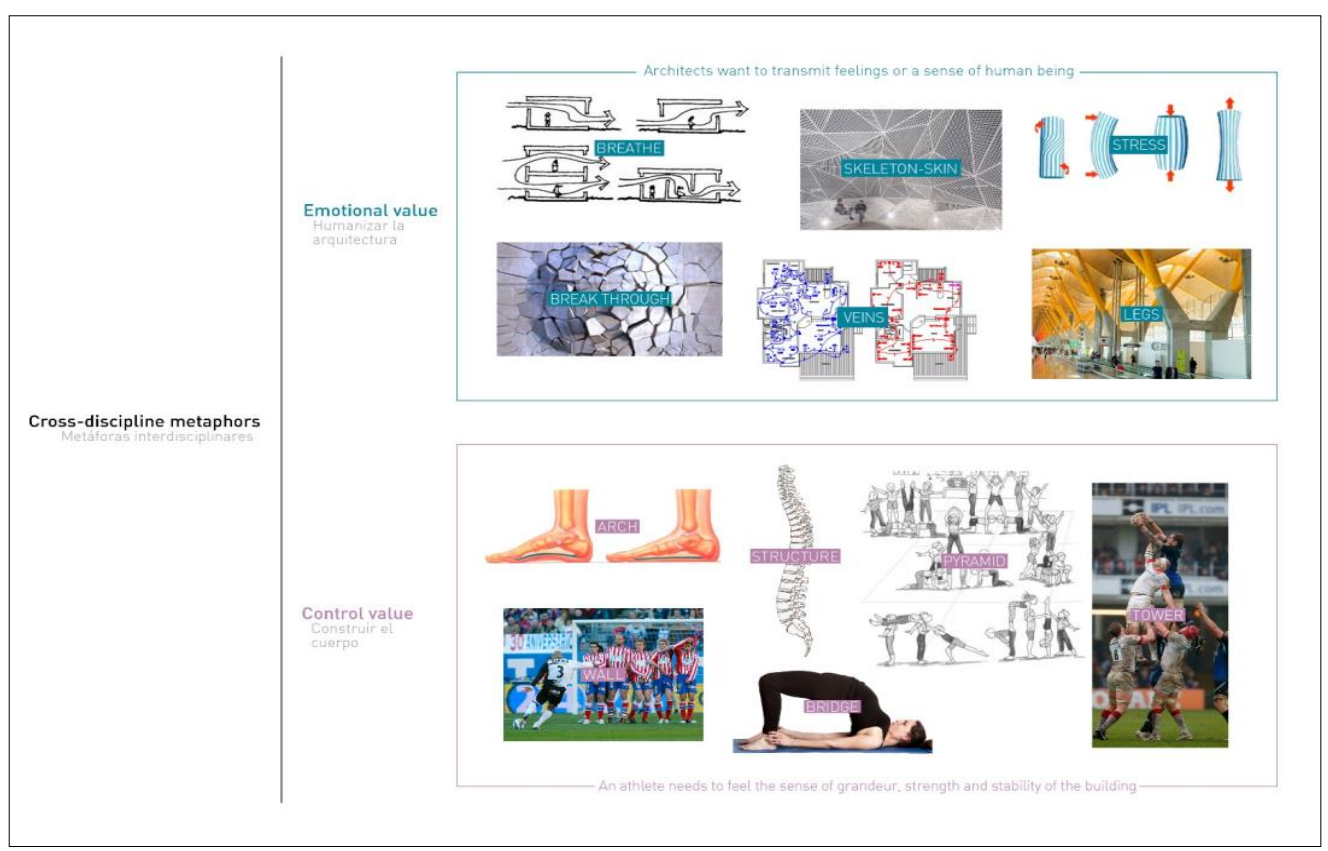

Figure 9: Cross-examples in real contexts

Message 9: The body is a human being that has pathology, emotion, symmetry and much more. 
The building is a strong structure that has to be worked out in terms of health, harmony and beauty.

\subsection{Video shoot}

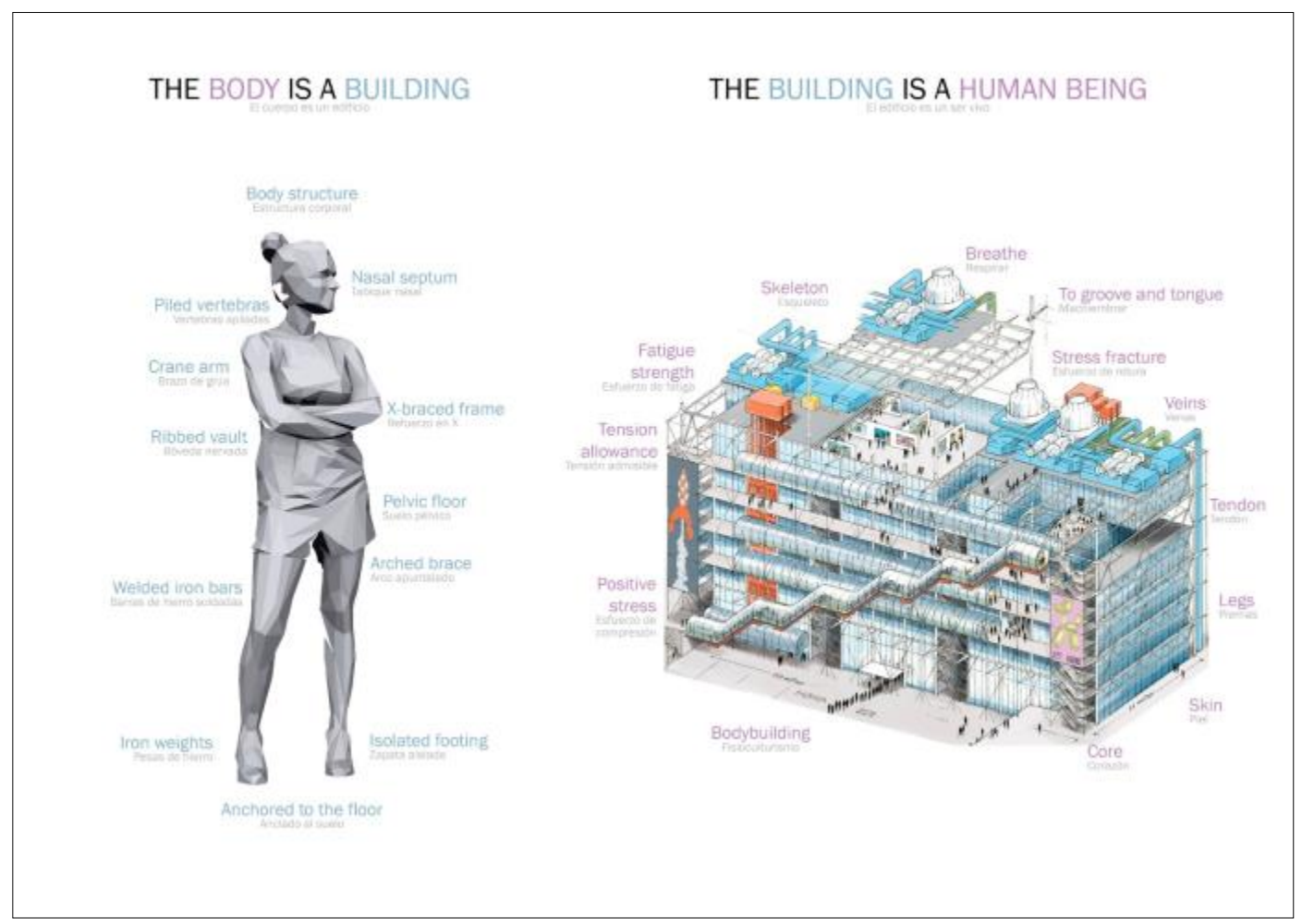

Figure 10: Visual metaphorical mappings

Message 10: The body is great building work and the building is an excellent human being!

The idea of starting and finishing with the same image provide a holistic perception in terms of memory learning to the students.

\section{Conclusions}

The final work of creating a Cross-Metaphorical Mapping Video Poster for ESL Students tool to be used for and to teachers and students increases students self-confidence knowledge and teachers self awareness in language communication into specific contexts and cross-cultural understandings. By using this multimedia tool, students' motivation and professional words knowledge improved. Also more cross-metaphorical maps should be developed in this way to keep working with the students' enthusiasm. However, as teachers we are aware of the amount of time consuming and effort to create a clear short poster video such as this one. Nevertheless, we feel the hardest task is always the first one and we don't hesitate 
to keep working on similar areas of material design. From here multitasks can be also design in order to improve students' communication in a natural environment that enhances classroom learning in a positive and engaging way. Somehow as Ramadan (2018) point out "Information and communication technology has been strongly admissible used in teaching" and learning process in the world and the modern digital learning materials is currently becoming a challenge in our daily routine class activities design.

\section{References}

Balte, R. \& Balciuniene, G. (2018) The Problem of Creativity: with what Images do Young People Come Up?. International Journal of Social Sciences, 4(2), pp.1690-1709. Retrieved from: http://www.grdspublishing.org/index.php/people/article/view/1610

Bloomer, K. \& C. Moore. (1977). Body, Memory, and Architecture. New Haven: Yale University Press.

Cameron, Lynne \& Graham Low (eds.) (1999). Researching and Applying Metaphor. Cambridge: Cambridge University Press.

Cuadrado-Esclapez, G., Argüelles Álvarez, I., Durán-Escribano, P., Gómez-Ortiz M-J., MolinaPlaza, S., Pierce-McMahon, J., Robisco-Martín M., Roldán-Riejos, A. \& ÚbedaMansilla, P. (2016). Bilingual Dictionary of Scientific and Technical Metaphors and Metonymies. Spanish-English/English-Spanish. London: Routledge.

DISCYT research group. Retrieved from: http://discyt.etsist.upm.es/

Gomez-Ortiz M.J. (2018). Estudio comparativo de las metáforas del deporte y el juego en la prensa económica y política española e inglesa E-JournALL, EuroAmerican Journal of Applied Linguistics and Languages 5, (1), August 2018. Retrieved from: http://www.ejournall.org/vol5_issue1_2018-2376905x-8-124/

Gromik, N.A (2011). Cell phone video recording feature as a language learning tool: A case study. Computer and Education. Elsevier.

Johnson, K. E. \& Golombek Paula R. (2016). Mindful L2 Teacher Education: A Sociocultural Perspective on Cultivating Teachers' Professional Development ESL \& Applied Linguistics Professional Series. London \& New York. Routledge.

Lakoff, G. \& Johnson M. (1980). Metaphors We Live By. Chicago: University of Chicago Press. 
Ramadan, A., \& Chen, X. (2018). Teachers' perceptions ICT integration in TVET classes: a case study in khartoum state-Sudan. International Journal of Social Sciences Vol 4, No 2.

Roldán-Riejos, A. \& Úbeda Mansilla, P. (2018).El léxico de la ingeniería y su aprendizaje: estudio exploratorio. E-JournALL, EuroAmerican Journal of Applied Linguistics and Languages 5, (1), August 2018.Retrieved from: http://www.ejournall.org/vol5_issue1_2018-2376905x-8-104/

Shanahan, L. Ortlieb \& E. McVee, M. (2015). Video Research in Disciplinary. Emerald Group Publishing Literacies.

Ubeda Mansilla P. (Director), Gomez-Ortiz. M. (Writer), \& Romero-Cañabete. E. (Screenwriter). (2018, August 23). A Cross-Metaphorical Mapping Video Poster for ESL Students [Video file]. Retrieved from: https://www.youtube.com/watch?v=rVrYGXE40Vw\&feature=youtu.be

Úbeda Mansilla, P. (2005). Conocimiento y lenguaje en el ámbito de los arquitectos. EGA: Revista de Expresión Gráfica Arquitectónica, 10, pp.112-119

Wai Meng Chan, Kwee Nyet Chin, Masanori Nagami, and Titima Suthiwan (2011). Media in Foreign Language Teaching and Learning. Walter de Gruyter. 